\title{
BIRD DISTRIBUTION IN ITERA CAMPUS AREA BASED ON VALUE CHANGES IN NORMALIZED DIFFERENCE VEGETATION INDEX (NDVI)
}

\author{
RIZKI KURNIA TOHIR ${ }^{1,2 *}$, MOHAMMAD ASHARI DWIPUTRA ${ }^{2,3)}$, AND FAJAR ISLAM SITANGGANG ${ }^{4)}$ \\ ${ }^{1)}$ Forestry Engineering Study Program, Institut Teknologi Sumatera, Lampung Selatan, 35365, Indonesia \\ ${ }^{2)}$ Geospatial Information Research Center, Institut Teknologi Sumatera, Lampung Selatan, 35365, Indonesia \\ ${ }^{3)}$ Marine Environmental Science Study Program, Institut Teknologi Sumatera, Lampung Selatan, 35365, Indonesia \\ 4) Biology Study Program, Institut Teknologi Sumatera, Lampung Selatan, 35365, Indonesia
}

*Email: rizki.tohir@rh.itera.ac.id

Accepted June 18, 2020 / Approved December 19, 2020

\begin{abstract}
Land-use change from a rubber plantation into the ITERA campus area causes an ecological transition. The components of ecology affected are vegetation and wildlife (bird). Geographic information systems can be used to assess the condition of vegetation and its relation to the ecological component. This study analyses bird diversity, vegetation condition through the NDVI value distribution, and then analyses the bird distribution based on vegetation condition. Observation in transect is the method for collecting bird distribution data. Analyses of vegetation condition was carried out based on NDVI. Analyses of bird distribution based on vegetation condition was carried out spatially by overlaying thematic maps of vegetation with bird distribution. This research found 28 bird species belonging to 18 families with diversity index (H') 1.84 . The highest abundance species were Lonchura punctulata, Passer montanus, and Hirundo tahitica. The NDVI values ranged from -0.64-0.87. ITERA vegetation conditions are divided into five classes: very rare vegetation (VRV), rare vegetation $(R V), m$ vegetation $(M V)$, dense vegetation class (DVC), and very dense vegetation (VDV). Total encounters with birds in this study were 753. The distribution of birds to the vegetation conditions in ITERA has a higher tendency and diverse vegetation have implications of birds to use the vegetation. In the VRV class, there were 4 encounters, $R V$ 37, MV 157, DVC 235, and VDV 315. Also, the number of bird species tends to increase along with the increasing vegetation value. Lonchura punctulata is a bird with the highest abundance in each vegetation class, followed by Passer montanus and Pycnonotus aurigaster.
\end{abstract}

Key words: bird distribution, ITERA, land-use change, vegetation condition

\section{INTRODUCTION}

The campus area of Institut Teknologi Sumatera (ITERA) is an area that is experiencing rapid development. ITERA was established on a rubber plantation area of 275 ha in 2012 which caused a change in the function of the plantation area into an office area. According to Stein et al. (2014), there is an interdependence relationship between biotic factors and the combination of abiotic factors that affect the composition of organism species in an area. Vegetation changes are indicated to lead to changes in the biotic and abiotic factors of an area.

Birds are one of the potential biodiversity found in ITERA area. The existence of birds in an area plays a great role in maintaining ecosystem stability (Mustari et al., 2014). Birds in ecosystems have a significant role in ecological processes (balancing the food chain), function as pollinators and distribution agents of seeds and ectomycorrhizae, and as the pest predators (Gullion, 2003; Ramdhani, 2006). In addition, birds bring a lot of benefits for humans, such as for research material, education, tourism, environmental indicators, sources of animal protein, and having aesthetic and economic values (Ramdhani, 2006). Bird communities can change with changes in their habitat. As reported by Barlow et al., (2006), the degradation and fragmentation of bird habitat may affect the bird communities. One of the research activities to examine the relationship between the existence of a species and the components of habitat which affect the species is by using the distribution model approach of species (Franklin, 2009).

Currently, geographical information systems are developing rapidly and are useful for many scientific fields, one of which is wildlife conservation. Spatial information is a significant component in managing biodiversity to determine management options based on physical, biological, social, and economic aspects (Prasetyo, 2017). Geographical information systems can be used to map wildlife distribution including birds in an area by processing coordinate data. This technology is very useful for managing wildlife conservation in an area. Moreover, the management of vegetation in an area is very important and it will determine the condition of its biodiversity.

Geographical information system technology can be used to assess the vegetation condition in an area, one of which is through the Normalized Difference Vegetation Index (NDVI) method. NDVI is one of the methods in spatial information systems to transform images in a vegetation study and is commonly used to process ecological data in forestry (Tucker, 1979; Dale, 1998). According to Sudiana and Diasmara (2008), NDVI is an index that shows the vegetation greenness in an area. This method will be very helpful in assessing the vegetation condition in ITERA area after the land 
clearing. Vegetation changes in ITERA area are indicated to affect the ecological condition of the existing birds. According to Kuswanda (2010), there is a relationship between vegetation composition and the diversity, abundance, and density of bird species in Batang Gadis National Park. Therefore, this study aims at analyzing the diversity of bird species, vegetation conditions in ITERA area using NDVI value, and bird distribution based on vegetation conditions in ITERA. This research can be used as the first source to complete the information on the condition of diversity in ITERA area so that it can be used as a basis to determine the management options in ITERA area.

\section{RESEARCH METHOD}

This research was conducted in ITERA which has an area of $275 \mathrm{Ha}$, from July 8 to August 22, 2019. The tools used in this research were cameras, GPS, distance meter, bird guide book, stationery, and notebook. Bird observation was carried out at 06.00-08.00 am and 04.00$06.00 \mathrm{pm}$. The observation time was adjusted to the time when birds were most active, which was in the morning and evening. The method used in this research was an observation on the observation path (Figure 1). Bird sampling was carried out by making six observation path in each area with a length of $\pm 1.3 \mathrm{~km}$, a width of $100 \mathrm{~m}$ (50 $\mathrm{m}$ to the right and $50 \mathrm{~m}$ to the left), and a distance between transects of $\pm 350 \mathrm{~m}$. The observation was repeated 3 times with a total of 18 observations on each observation path. The data collection technique on the transect was carried out by observing data on bird species, the number of individuals, tagging the location of the observation points, and calculating the distance between the position of the bird and the observation path to determine the coordinate point of the bird.

Data analysis of bird diversity and abundance was carried out using the following formulas:

a. Shannon-Wiener Species Diversity Index (Magguran, 2004)

$$
H^{\prime}=-\sum p i \ln p i
$$

Description: H' = Species diversity index; pi = Richness value (ni/Ni)

\section{b. Relative Abundance}

$$
P i(\%)=\frac{N i}{N} \times 100 \%
$$

Description: $\mathrm{Pi}=$ Relative abundance; $\mathrm{Ni}=$ Total individuals of each species; $\mathrm{N}=$ Total individuals of all species

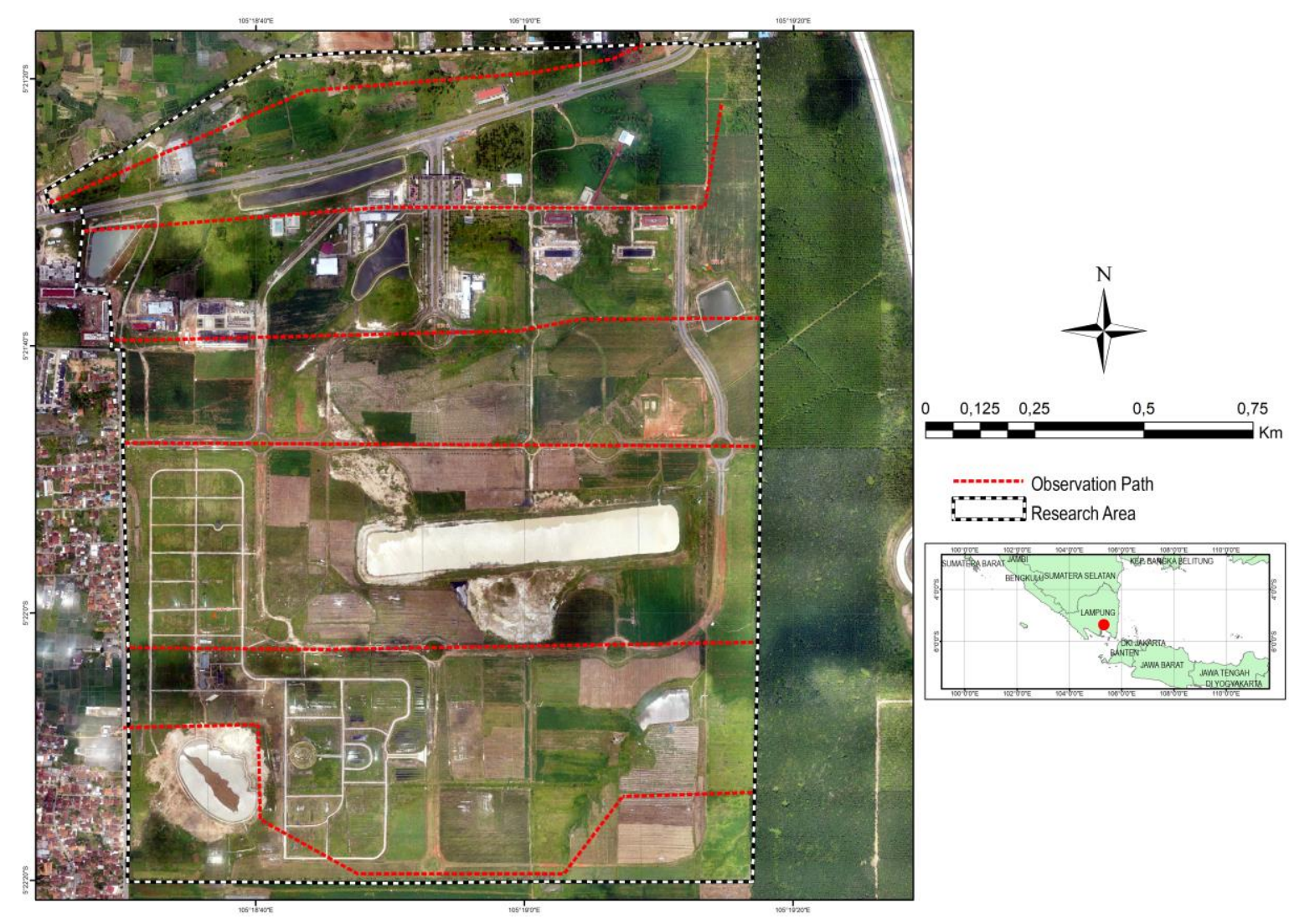

Figure 1. Campus area of Institut Teknologi Sumatera and Observation Path 
The analysis of vegetation conditions was carried out in these three stages:

a. Image Pre-Processing

Satellite image data that had been obtained were then processed with radiometric and atmospheric correction processing. The radiometric correction was conducted by converting raw numerical data (digital number) of satellite images into radians. Atmospheric correction was then carried out to correct the difference in the reflection values due to the difference in earth-sun distance at each recording date (Muchsin and Fibriawati, 2017).

b. Supervised Classification

Supervised classification was carried out to obtain land cover information. In this research, the land cover was limited to two classes, which were vegetation area and non-vegetation area. The algorithm used in this classification is the maximum likelihood algorithm (Projo, 2012). This classification process requires the data from field sampling which will be validated with the training area that is previously made (Dwiputra et al., 2019). This research used 137 training areas.

c. Analysis of normalized difference vegetation index (NDVI) distribution

NDVI is an index that shows the vegetation greenness in an area. NDVI values may range from -1 (non-vegetation) to +1 (vegetation with the highest level of greenness). NDVI is commonly used as an accurate indicator for assessing the level of vegetation cover (Soewarso, 2003). NDVI analysis was carried out based on Rouse et al., (1974) by processing the Sentinel-2 image acquired in 2019 using NIR band (Near Infrared) and red band (RED) with the following formula:

$$
N D V I=\frac{(N I R-R E D)}{(N I R+R E D}
$$

Description: NIR (Sentinel-2 image Band 8); RED (Sentinel-2 image Band 4)

NDVI transformation would produce a value between -1 to +1 . An NDVI value between +0.1 to +0.7 is considered as a vegetation class and a value greater than +0.7 represents a better level of vegetation health (Prahasta, 2008). Furthermore, the NDVI values were classified using the formula below:

$$
K L=\frac{x t-x r}{k}
$$

Description: KL (interval class); Xt (highest value); $\mathrm{Xr}$ (lowest value); K (expected class)

In this research, 5 classes of NDVI values were classified following the research of Sari et al. (2005) with modifications adjusted to the field conditions: very rare vegetation (VRV), rare vegetation (RV), medium vegetation (MV), dense vegetation (DV), and very dense vegetation (VDV).
Analysis of bird distribution was carried out to analyze the composition of bird communities at certain land cover types based on the NDVI value. The analysis of this distribution was conducted spatially by overlaying the bird distribution map and the vegetation condition class value map based on the NDVI value. The results of this overlay showed the percentage of birds in each vegetation condition. The bird distribution in each vegetation condition represents how the ecological pattern of bird behavior is related to the life needs such as food and shelter. The data of food and shelter needs were analyzed using secondary data.

\section{RESULT AND DISCUSSION}

\section{Bird Diversity and Relative Abundance in ITERA}

The results of the research showed that the bird species found in ITERA area were 28 species from 17 families with a diversity value $\left(\mathrm{H}^{\prime}\right)$ of 1.84 (Table 1$)$. The research by Apriliano et al., (2018) in a campus close to ITERA, which was UIN Raden Intan Lampung (UIN-RIL), showed that there were 24 bird species from 16 families. ITERA has more types of bird (4 species) apart from being indicated due to the difference in areas (UIN-RIL 51.8 ha; ITERA 275 ha), ITERA also has more types of habitat (forest, water bodies, open area, and shrubs), and human activities at ITERA in undeveloped locations are less compared to the activities at UIN-RIL. The bird diversity value in ITERA is almost the same as those in the coffee plantation landscape (817 ha) of 1.92 (Kamal et al. 2013). Therefore, the diversity value in areas with vegetation that is disturbed by community activities has a relatively close diversity value.

The species with the highest abundance value were scaly-breasted munia (54\%), eurasian tree sparrow (10.5\%), and pacific swallow (7.5\%). Scaly-breasted munia and eurasian tree sparrow have a high abundance value presumably due to the open space observation area and vegetation that provide a source of food such as grains from grass and shrubs (MacKinnon et al., 2010). Pacific swallows are insectivorous birds and eat small fish. The potential for insects in ITERA area is very high due to the shrubs and grassland. The presence of an "embung" (artificial lake) in ITERA also supports swallows looking for small fish. In addition, eurasian tree sparrow and pacific swallow are cosmopolitan birds that have a fairly wide distribution and have high adaptability in various habitats. These types of bird can be associated with humans and live in groups around the settlements (Mackinnon et al., 2010). 
Table 1 List of bird species in ITERA

\begin{tabular}{|c|c|c|c|c|}
\hline No & Family & Type & Scientific Name & Guild \\
\hline 1 & Accipitridae & Black-Winged Kite & Elanus caeruleus & Carnivore \\
\hline 2 & Alcedinidae & White-Throated Kingfisher & Halcyon smyrnensis & Piscivore \\
\hline 3 & Alcedinidae & White-Collared Kingfisher & Halcyon chloris & Piscivore \\
\hline 4 & Apodidae & Cave Swiftlet & Collocalia linchi & Insectivore \\
\hline 5 & Ardeidae & Cinnamon Bittern & Ixobrychus cinnamomeus & Piscivore \\
\hline 6 & Ardeidae & Javan Pond-Heron & Ardeola speciosa & Piscivore \\
\hline 7 & Ardeidae & Great Egret & Ardea alba & Piscivore \\
\hline 8 & Ardeidae & Purple Heron & Ardea purpurea & Piscivore \\
\hline 9 & Artamidae & White-Breasted Woodswallow & Artamus leucorynchus & Insectivore \\
\hline 10 & Caprimulgidae & Savanna Nightjar & Caprimulgus affinis & Insectivore \\
\hline 11 & Columbidae & Zebra Dove & Geopelia striata & Granivore \\
\hline 12 & Columbidae & Spotted Dove & Streptopelia chinensis & Granivore \\
\hline 13 & Cuculidae & Lesser Coucal & Centropus bengalensis & Insectivore \\
\hline 14 & Cuculidae & Banded Bay Cuckoo & Cacomantis sonneratii & Insectivore \\
\hline 15 & Hirundinidae & Pacific Swallow & Hirundo tahitica & Insectivore \\
\hline 16 & Laniidae & Long-Tailed Shrike & Lanius schach & Insectivore \\
\hline 17 & Motacillidae & Australasian Pipit & Anthus novaeseelandiae & Insectivore \\
\hline 18 & Ploceidae & Javan Munia & Lonchura leucogastroides & Granivore \\
\hline 19 & Ploceidae & Scaly-Breasted Munia & Lonchura punctulata & Granivore \\
\hline 20 & Ploceidae & Eurasian Tree Sparrow & Passer montanus & Granivore \\
\hline 21 & Pycnonotidae & Sooty-Headed Bulbul & Pycnonotus aurigaster & Frugivore \\
\hline 22 & Pycnonotidae & Yellow-Vented Bulbul & Pycnonotus goiavier & Frugivore \\
\hline 23 & Rallidae & White-Breasted Waterhen & Amaurornis phoenicurus & Omnivore \\
\hline 24 & Rallidae & Slaty-Breasted Rail & Gallirallus striatus & Insectivore \\
\hline 25 & Silviidae & Zitting Cisticola & Cisticola juncidis & Insectivore \\
\hline 26 & Silviidae & Ashy Tailorbird & Orthotomus ruficeps & Insectivore \\
\hline 27 & Sturnidae & Common Myna & Acridotheres tristis & Insectivore \\
\hline 28 & Turnicidae & Barred Buttonquail & Turnix suscitator & Omnivore \\
\hline
\end{tabular}

\section{Vegetation Condition Based on Normalized Difference Vegetation Index (NDVI)}

The vegetation of ITERA area has changed since the development of ITERA began from a rubber plantation. Based on the results of NDVI analysis in the entire ITERA area, NDVI value range was obtained between -0.64 to 0.87 . According to Prasetyo (2017), the higher the NDVI value, the denser the land cover is. The NDVI value $\leq 0.1$ at the research location indicates that the non-vegetation land cover is in the form of an "Embung" (artificial lake) (Sari et al., 2005). This is in line with the research of Febrianti and Sofan (2014) which shows that the NDVI value $<0$ indicates cover in the form of clouds, ice, snow, and water bodies, and the values from 0 to 0.1 are generally the characteristics of rocks and empty land. The highest NDVI value at the research location was 0.87 referring to an area that still had old rubber trees (Hevea brasiliensis) that remained from rubber plantations and the ITERA Arboretum which was dominated by Acacia mangium as a result of reforestation activities. According to Sari et al. (2005); Febrianti and Sofan (2014), the values $>0.8$ represent an area with high vegetation cover/tropical rain forest. Therefore, the results of NDVI analysis in this research are acceptable since they are in accordance with the results of other studies and actual condition in the field.

Analysis of vegetation conditions in ITERA area was carried out by dividing the NDVI value into five classes. NDVI class values for very rare vegetation condition (VRV) ranged from -0.64-0.10 (14.60 Ha), rare vegetation class (RV) 0.10-0.27 (25.84 Ha), medium vegetation class (MV) 0.27-0.43 (53.68 Ha), dense vegetation class (DV) 0.43-0.58 (86.09 ha), and very dense vegetation class (VDV) $0.58-0.78$ (97.58 Ha) (Figure 2). The results of the analysis show that there are differences and increases in the area from VRV to VDV 
classes. It is related to the secondary succession process in the area, community plantation activities and revegetation activities in ITERA area.

The secondary succession process occurred in ITERA area after land clearing from a rubber plantation to an open area, then the secondary succession was started with the growth of grass and shrubs. According to Van Dijk et al. (1987), the vegetation index pattern increases since the beginning of growth (vegetative phase) and reaches its peak at the maximum vegetative growth, then decreases in the generative growth phase. Therefore, from the results of the data analysis of NDVI class values, ITERA now has a vegetation index pattern in the increasing phase, seen from the trend of area increase from VRV to VDV classes.
The results of field verification for each class (Table 2) show that some locations of ITERA area are in the early stage of succession, indicated by the growth of pioneer vegetation such as grass and shrubs. In addition to natural succession, ITERA vegetation develops due to revegetation activities and community agricultural activities so that the vegetation conditions of ITERA area begin to improve. The results of image processing obtained the observed percentage in each vegetation condition (NDVI class). In general, the observed percentage in each NDVI class ranges from $\pm 30 \%$ of the total area of each class except for the VRV class because it is a water body. Therefore, in this research, it is considered that the effort to identify the bird distribution in each vegetation condition is relatively the same and comparable.

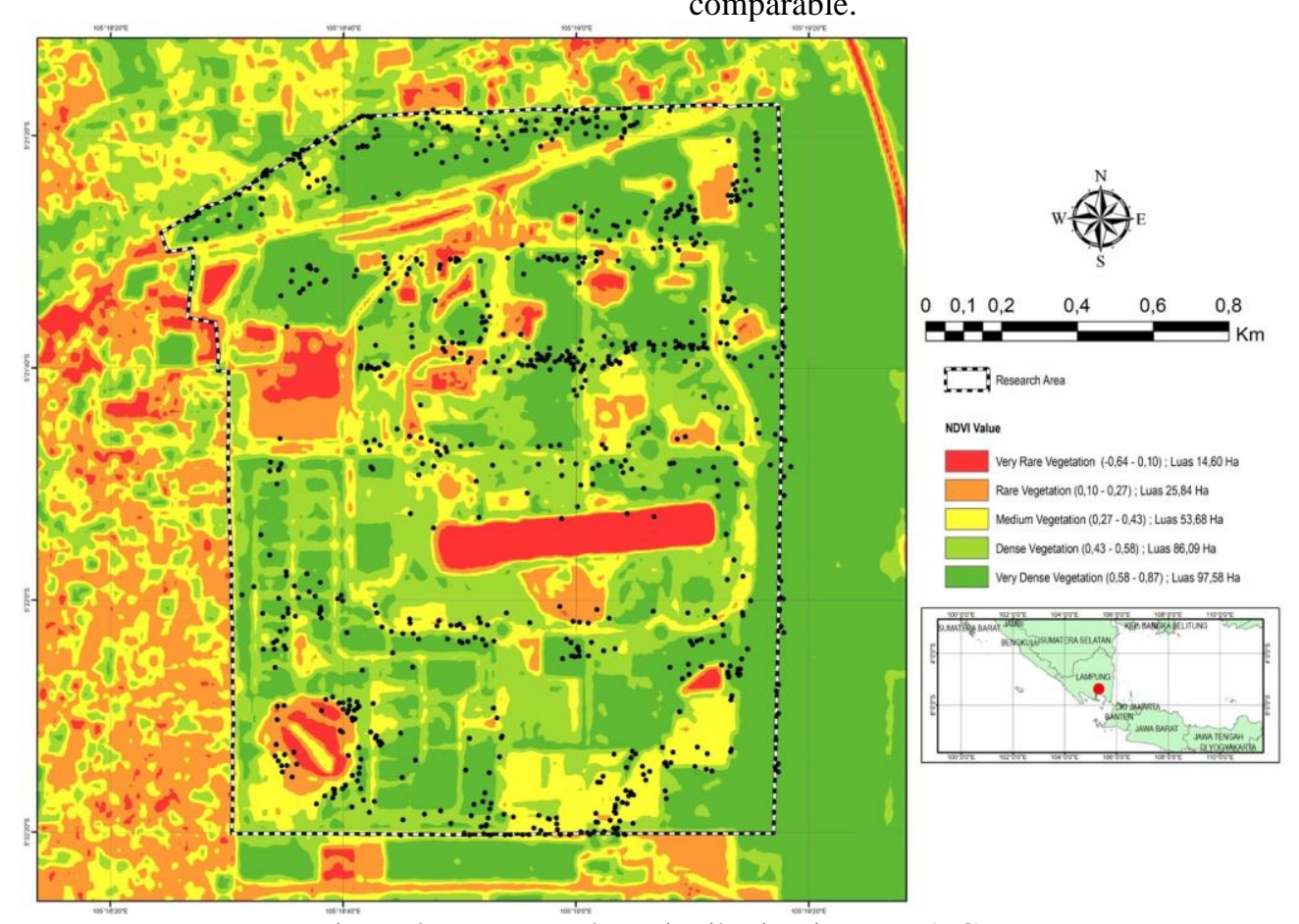

Figure 2. NDVI Value Distribution in ITERA Campus

Table 2 Results of field verification in each NDVI class and proportion of the observed area

\begin{tabular}{|c|c|c|c|c|c|}
\hline No. & NDVI Class & Field Verification & $\begin{array}{l}\text { Area } \\
(\mathrm{Ha})\end{array}$ & $\begin{array}{l}\text { Observed area in } \\
\text { transect } \\
(\mathrm{Ha})\end{array}$ & $\begin{array}{c}\% \\
\text { observed }\end{array}$ \\
\hline 1 & $\begin{array}{l}\text { Very rare vegetation } \\
(\text { VRV) }\end{array}$ & Water body (embung) and building & 14.6 & 2.67 & 18.29 \\
\hline 2 & $\begin{array}{l}\text { Rare vegetation } \\
(\mathrm{RV})\end{array}$ & Open space dominated by land & 25.84 & 8.99 & 34.81 \\
\hline 3 & $\begin{array}{l}\text { Medium vegetation } \\
\text { (MV) }\end{array}$ & $\begin{array}{l}\text { Open space of road and grass } \\
\text { vegetation }\end{array}$ & 53.68 & 19.90 & 37.07 \\
\hline 4 & $\begin{array}{l}\text { Dense vegetation } \\
\text { (DV) }\end{array}$ & $\begin{array}{l}\text { Open space dominated by shrubs and } \\
\text { agricultural crops (watermelon, corn, } \\
\text { and cassava) }\end{array}$ & 86.09 & 28.40 & 32.99 \\
\hline 5 & $\begin{array}{l}\text { Very dense } \\
\text { vegetation (VDV) }\end{array}$ & $\begin{array}{l}\text { Combination area of grass, shrubs } \\
\text { and trees (stake and pile level) }\end{array}$ & 97.58 & 30.69 & 31.45 \\
\hline
\end{tabular}




\section{Bird Distribution Based on Vegetation Conditions in ITERA Area}

In general, bird species are scattered throughout the observation path. The bird distribution map shows the bird encounter points throughout the observation path (Figure 3). The path with the highest species richness was path 6 with 22 species and path 1 with 21 species. These two paths are edge areas and ecotone habitats that do not have high disturbance and are bordered by community plantations. In line with the research conducted in Gunung Walat Educational Forest (GWUF), the individual abundance and bird species richness is higher in ecotone habitats (Tamnge et al., 2016). According to Mardiastuti (2015), edge effects have an influence on the diversity and abundance of individual birds because they provide a more favorable habitat for sustaining their lives.

The overlay results of bird distribution in ITERA vegetation conditions obtained 3 species (4 encounters) in the VRV class; 12 types (37 encounters) in the RV class; 21 types (157 encounters) in the MV class; 28 species (235 encounters) in class DV; and 23 species (315 encounters) in the VDV class (Figure 4). The highest bird composition was found in the DV class with an open area dominated by shrubs and agricultural crops (watermelon, corn, and cassava). The combination of grass and shrub vegetation provides opportunities for birds to easily forage. This combination is more beneficial for the birds. According to Tews et al. (2004), the more diverse types of vegetation in a habitat, the more it will further support the food for birds so that they will get various choices of types of food. A good habitat for bird survival is a habitat that can protect them from disturbances and can provide them daily needs (Hernowo and Prasetyo, 1989).

The analysis results of bird distribution based on vegetation conditions have a tendency that the higher the value of the vegetation, the higher the bird encounters (Figure 5). The increase in bird encounters occurs from low to high vegetation types. Vegetation is part of the habitat which provides the needs of animals for shelter, breeding and food sources (Fleming, 1992). According to Tews et al. (2004) in their study, they stated that there is a positive correlation between habitat heterogeneity and wildlife species diversity. Changes in habitat use by birds are greatly influenced by vegetation conditions and the selection of habitat use by birds according to their needs (Lambert, 1992; Wiens, 1992).

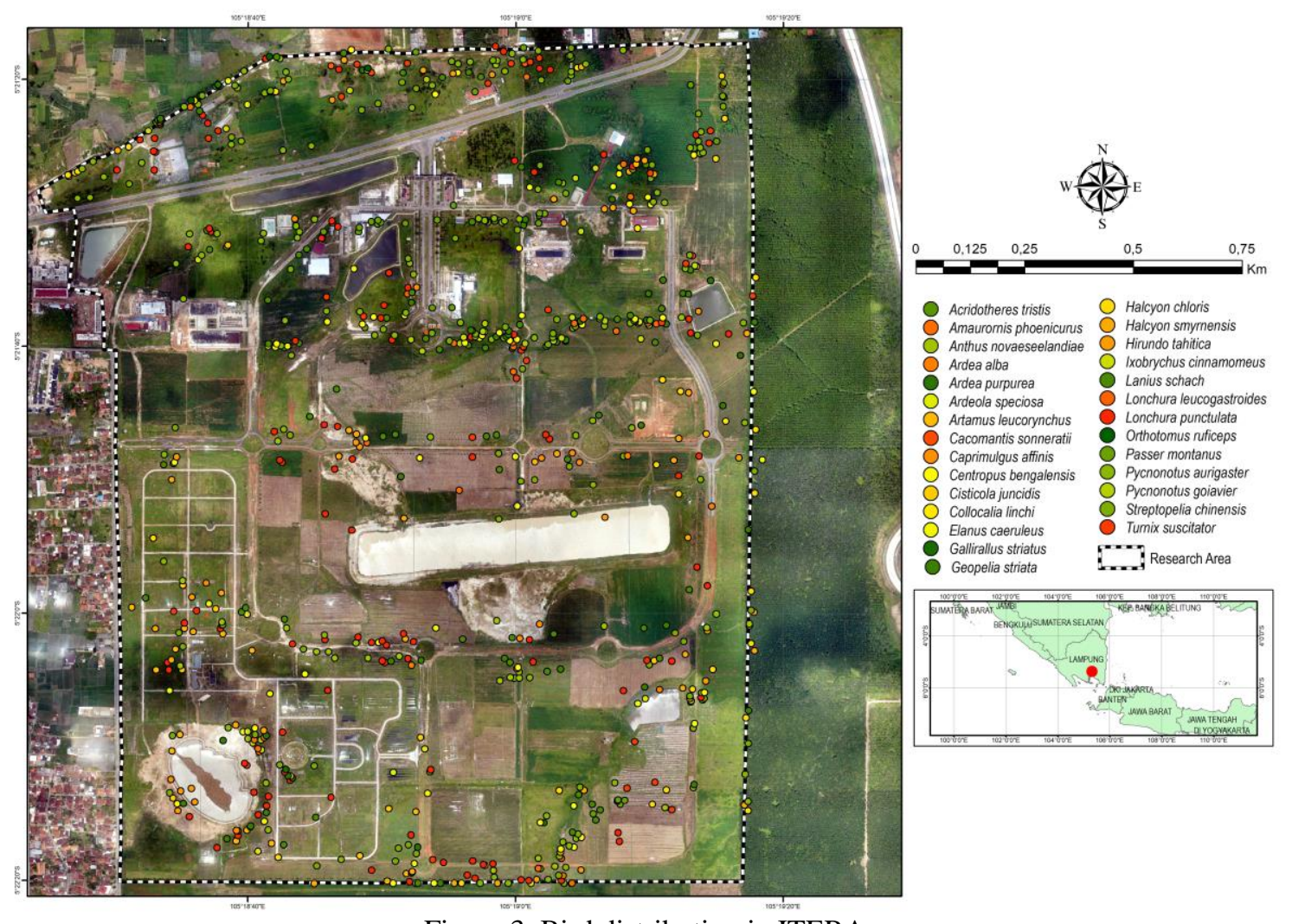

Figure 3. Bird distribution in ITERA 


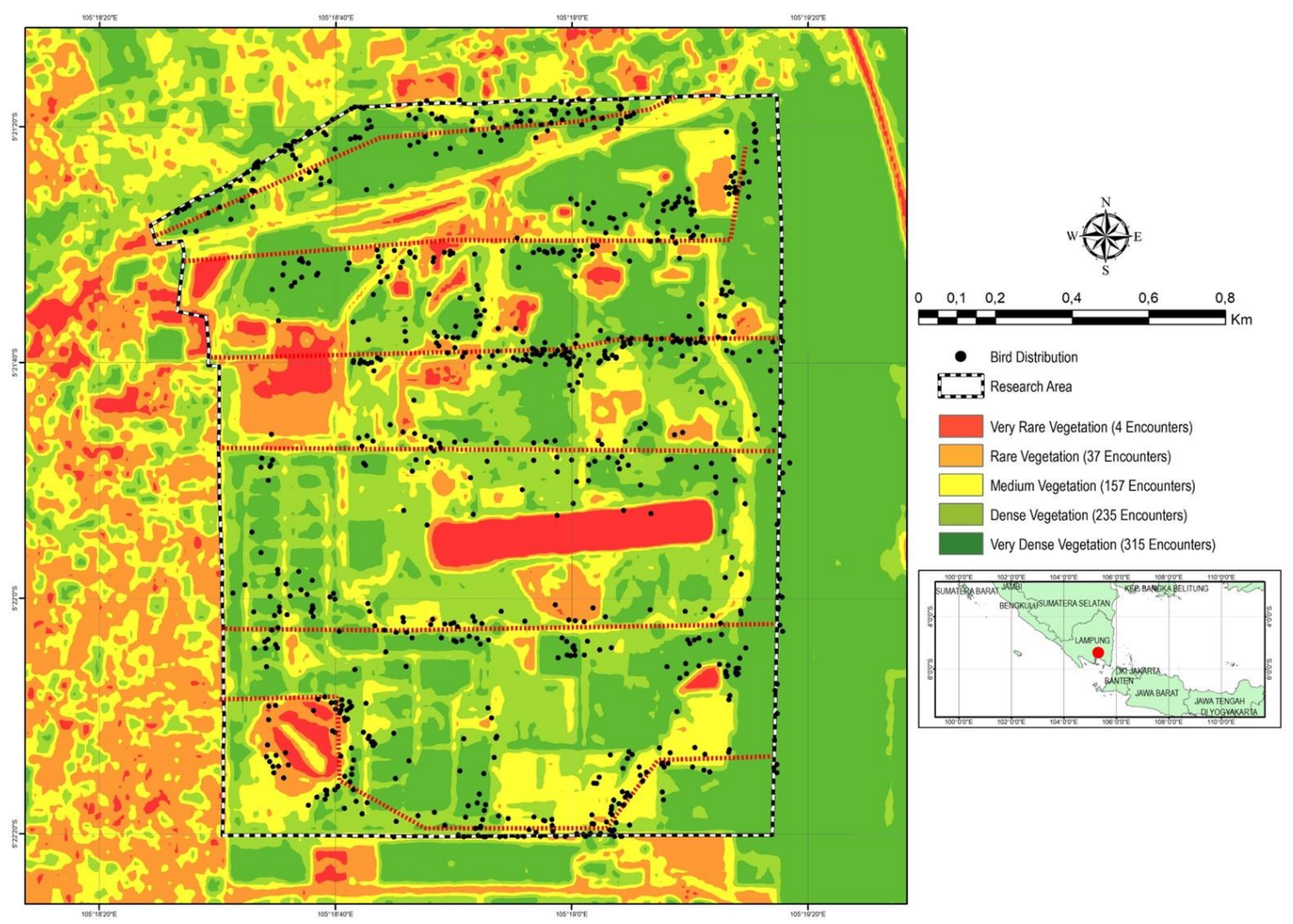

Figure 4. Bird distribution based on ITERA vegetation conditions

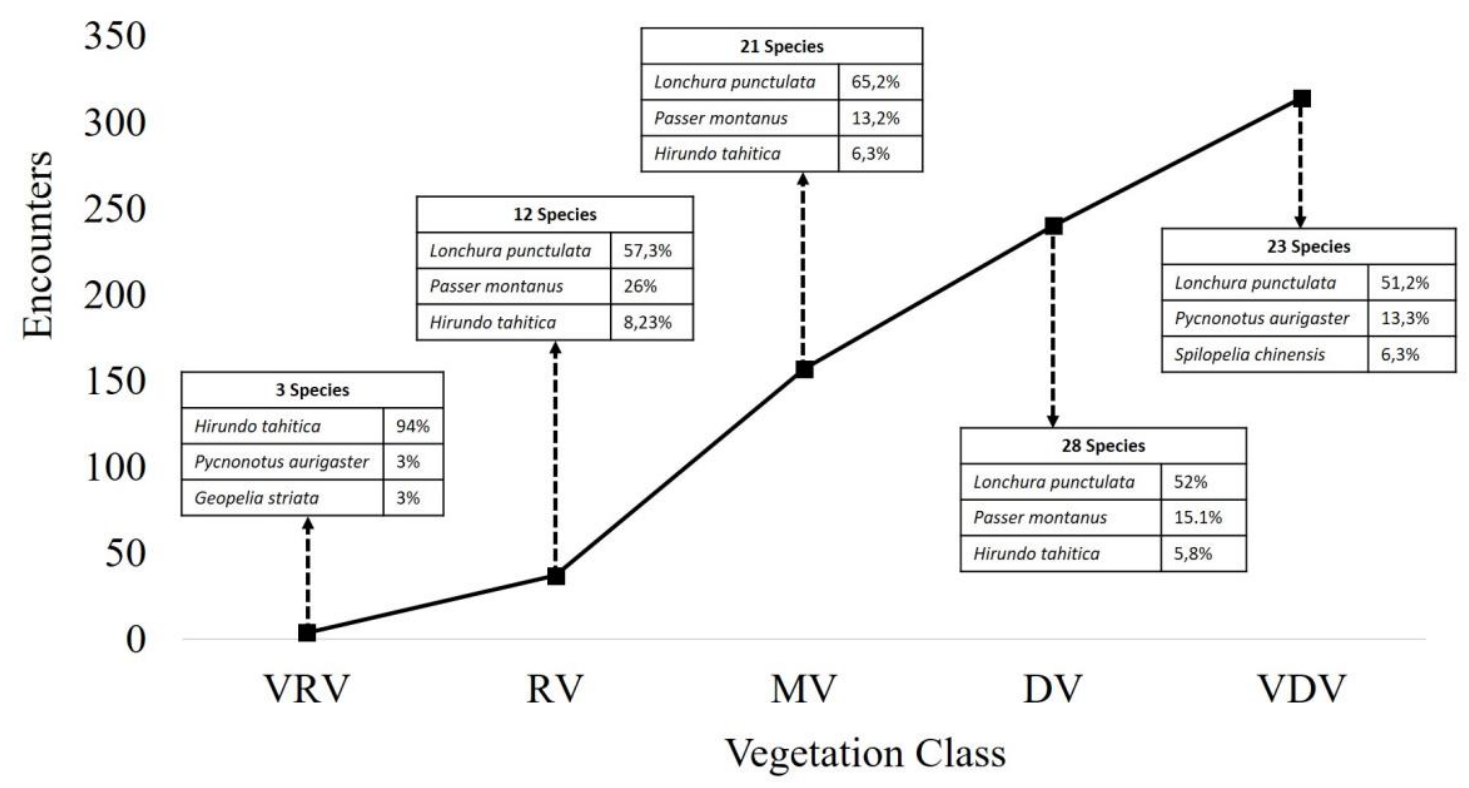

Figure 5. Total encounters, bird species and relative abundance of birds in each vegetation class

Figure 5 shows the total encounters, the number of species, and the relative abundance value of birds in each vegetation class. The number of bird species tends to increase along with the increase in vegetation value. DV class has the largest number of species. It is because DV class provides food for granivorous and insectivorous birds. The dominance of grass and shrub vegetation supports the existence of grasshoppers and crickets on the soil, grass, and shrubs as a source of food for insectivorous birds (Erniwati, 2003). In the VRV class, 
the pacific swallow has the highest abundance by $94 \%$. It is because in the VRV class there are several sources of water that are used by pacific swallows to find small fish. According to Haslem and Bennett (2008), the distribution of bird species is influenced by the availability of habitat resources, for instance the food sources.

Scaly-breasted munia has the greatest abundance value in each vegetation class, followed by the eurasian tree sparrow and sooty-headed bulbul. According to Mackinnon (1990), the main food for scaly-breasted munia and eurasian tree sparrow are rice and grass seeds. Sooty-headed bulbuls are frugivore. Therefore, the presence of these birds is highly correlated with the condition of ITERA land which provides abundant food for them.

If it is analyzed based on habitat and behavior factors, scaly-breasted munia is abundant because it has habitat characteristics in open cultivated lands, semicultivated lands and grasslands, and using tree vegetation for nesting and reproduction (Coates and Bishop, 2000; Fitri et al., 2014). The eurasian tree sparrow and sootyheaded bulbul have high abundance because they tend to flock and have a fairly wide distribution and have high adaptability in various habitats. Eurasian tree sparrow and sooty-headed bulbul are associated with humans and live in groups around settlements (Mackinnon et al., 2010).

\section{CONCLUSION}

Analysis of bird distribution based on vegetation conditions conducted in ITERA is a pioneer research. The results found 28 species from 17 bird families in ITERA campus, with a diversity value ( $\left.\mathrm{H}^{\prime}\right)$ of 1.84 . Scaly-breasted munia, Eurasian tree sparrow, and pacific swallow were the species with the highest abundance value. NDVI values in the entire ITERA area ranged from -0.64 to 0.87 . Vegetation conditions in ITERA were divided into five classes: very rare vegetation (VRV), rare vegetation $(\mathrm{RV})$, medium vegetation (MV), dense vegetation (DV), and very dense vegetation (VDV). The results showed that there was an increase in the area of each vegetation condition from VRV to VDV classes. It is related to the natural succession process, agricultural activities, and revegetation activities that occur in ITERA area. The higher the NDVI class, the more diverse the vegetation conditions are. The total number of encounters with birds in this research was 753. Bird distribution on vegetation conditions in ITERA has a tendency to increase as well as the variety of vegetation. Therefore, birds will increasingly take advantage of these vegetation conditions. In the VDV class, there were 4 encounters, RV 37 encounters, MV 157 encounters, DV 235 encounters, and VDV 315 encounters. Moreover, the number of bird species tends to increase along with the increase in vegetation value. Scaly-breasted munia has the greatest abundance value in each vegetation class, followed by euranian tree sparrow and pacific swallow. This research concludes that the better the vegetation conditions, the more diverse the bird diversity will be.

\section{ACKNOWLEDGMENTS}

This research receive funding from Institut Teknologi Sumatera with the scheme "Penelitian Hibah ITERA Smart” [B/347/IT9.C1/PT.01.03/2019].

\section{REFERENCES}

Apriliano A, Anwar C, Pawhestri SW, Satiyarti RB. 2018. Keanekaragaman burung di Kampus UIN Raden Intan Lampung [Skripsi]. LampungL UIN Raden Intan Lampung.

Barlow J, Peres CA, Henriques LMP, Stoufer PC, Wunderle JM. 2006. The responses of understorey birds to forest fragmentation, logging and wildfires: An amazonian synthesis. Biological Conservation. 128(1): 182-1923.

Coates BJ, Bishop KD. 2000. A Guide to the birds of Wallace: Sulawesi, the Moluccas and Lesser Sunda Island, Indonesia. Bogor: Birdlife Internationalindonesia Programme \& Dove Publications Pty. Ltd.

Dale VH. 1998. Management of Forests as Ecosystems: A Success Story or A Challenge Ahead?. M. L. Pace and P. M. Graffman, Eds. Success, Limitations, and Frontiers in Ecosystem Science. New York: SpringerVerlag.

Dwiputra MA, Kurnia R, Riani E. 2019. Penggunaan data citra satelit landsat multitemporal untuk monitoring kondisi ekosistem mangrove di Teluk Kulisusu Kabupaten Buton Utara. Journal of Science and Applicative Technology. 3(1): 1-8.

Erniwati 2003. Belalang (orthoptera) dan kerabatnya didalam: Amir M Kahono S(ed). Serangga taman nasional gunung halimun Jawa Barat. Biodiversity conservation project. Hal 63-76.

Febrianti N, Sofan P. 2014. Ruang terbuka hijau di DKI Jakarta berdsarkan analisis spasial dan spektral data landsat 8. Seminar Nasional Penginderaan Jauh.

Fitri, Rizaldi, Novarino W. 2014. Karakteristik sarang bondol peking Lonchura punctulata (Linnaeus 1758) di Kawasan Kampus Universitas Andalas. J.Bio. UA. 3(4): 324-331.

Fleming TH. 1992. How Do Fruit and Nectar Feefing Birds and Mammals Track Their Food Resources. In: Hunter MD, Takayuki O, and Peter WP, editor. Effects of Resource Distribution in Animal-Plant Interaction. New York: Academic Press.

Franklin J. 2009. Mapping Species Distribution : Spatial inference and prediction. Cambrideg: Cambridege University Press.

Gullion GW. 2003. Forest and Wildlife Management in Introduction to forest Ecosystems Science and Management, 3rd edition. Hoboken, John Wiley and Sons Inc. 
Haslem A, Bennett AF. 2008. Bird in agriculture mosaics: the influence of landscape pattern and countryside heterogenity. Ecological Aplication. 18:185-196.

Hernowo JB, Prasetyo LB. 1989. Konsep ruang terbuka hijau di kota sebagai pendukung pelestarian burung. Media Konservasi. 2(04): 61-71.

Kamal S, Mahdi N, Senja N. 2013. Keanekaragaman jenis burung pada perkebunan kopi di Kecamatan Bener Kelipah Kabupaten Bener Meriah Provinsi Aceh. Jurnal Biotik 1(2): 73-79.

Kuswanda W. 2010. Pengaruh komposisi tumbuhan terhadap populasi burung di Taman Nasional Batang Gadis, Sumatera Utara. Jurnal Penelitian Hutan dan Konservasi Alam. 7(2): 193-213.

Lambert FR. 1992. The consequence of selective logging for bornean lowland forest birds. Condor. 94: 443450.

MacKinnon J, Phillipps K, van Balen B. 2010. LIPI- Seri Panduan Lapangan Burung-Burung di Sumatera, Jawa, Bali, dan Kalimantan (Termasuk Sabah, Sarawak, dan Brunei Darussalam). Bogor: Burung Indonesia.

MacKinnon J. 1990. Field Guide to the Birds of Java and Bali. Yogyakarta: Gajah Mada University press

Magguran AE.2004. Measuring Biological Diversity. Oxford: Blackwell Publishing.

Mardiastuti A. 2015. Ekologi Satwa pada Lanskap yang Didominasi Manusia. Bogor: Fakultas Kehutanan IPB.

Muchsin F, Fibriawati L. 2017. Koreksi atmosfer citra Landsat-8 menggunakan Metode 6S. Proceeding Seminar Nasional Sains Atmosfer (SNSA) 2017. pp. 100-104.

Mustari AH, Zulkarnain I, Dones R. 2014. Species diversity and distribution of mammals in IPB Dramaga Campus, Bogor. Media Konservasi 19 (2): $117-125$

Prahasta E. 2008. Remote Sensing. Bandung: Informatika Bandung.

Prasetyo LB. 2017. Pendekatan Ekologi Lanskap untuk Konservasi Biodiversitas. Bogor: Fakultas Kehutanan IPB.

Projo D. 2012. Pengantar Penginderaan Jauh Digital. Yogyakarta: PUSPICS Fakultas Geografi, Universitas Gadjah Mada .
Ramdhani D. 2006. Studi Hubungan Keanekaragaman Burung dengan Lansekap Taman Kota Bandung (Thesis). Bandung: Universitas Padjadjaran.

Rouse JW, Haas RH, Schell JA, Deering DW. 1974. Monitoring Vegetation Systems in The Great Plans with ERTS. In : Fraden SC, Marcanti EP, dan Becker MA. Third ERTS-1 Symphosium. pp.309317.

Sari DK, Hermawan ET, Hudman G. 2005. Study On Vegetation Cover Change In The Province of South Kalimantan Using RGB-NDVI Unsupervised Classification Method. Map Asia Conference. Jakarta

Soewarso. 2003. Penyusunan pencegahan kebakaran hutan rawa gambut dengan menggunakan model prediksi [disertasi]. Bogor: Program Pascasarjana, Institut Pertanian Bogor.

Stein A, Gerstner K, Kreft H. 2014. Environmental heterogenity as a universal driver of species richness across taxas, biomes, and spatial scales. Ecology Letters, 17: 866-880.

Sudiana A, Diasmara E. 2008. Analisis indeks vegetasi data satelit NOAA/AVHRR dan TERRA/AQUAMODIS. Seminar on Intelligent Technology and Its Applications.

Tamnge F, Mulyani YA, Mardiastuti A. 2016. Efek tepi pada komunitas burung antara tegakan agathist dan puspa di Hutan Pendidikan Gunung Walat, Jawa Barat. Media Konservasi 21(1), 83-90.

Tews J, Brose U, Grimm V, Tielborger K, Wichmann MC, Schwager M, Jeltsch F. 2004. Animal species diversity driven by habitat heterogeneity/ diversity: the importance of keystone structures. J. Biogeogr. 31: 79-92.

Tucker CJ. 1979. Red and photographic infrared linear combinations for monitoring vegetation. Rem. Sensing Environ. 8: 127-150.

van Dijk A, Callis S, Sakamoto C, Decker W. (1987). Smoothing vegetation index profiles: An alternative method for reducing radiometric disturbance in NOAA/ AVHRR data. Photogrammetric Engineering and Remote Sensing, 53, 1059-1067.

Wiens JA. 1992. The Ecology of Birds Communities. Vol. I. Foundations and Patterns. Cambridge: Cambridge University Press. 